Bryn Mawr College

Scholarship, Research, and Creative Work at Bryn Mawr College

Classical and Near Eastern Archaeology Faculty

Research and Scholarship

Classical and Near Eastern Archaeology

1965

\title{
A Head of Herakles in the Philadelphia University Museum
}

Brunilde S. Ridgway

Bryn Mawr College, bridgway@brynmawr.edu

Let us know how access to this document benefits you.

Follow this and additional works at: https://repository.brynmawr.edu/arch_pubs

Part of the History of Art, Architecture, and Archaeology Commons

\section{Custom Citation}

Ridgway, Brunilde S. 1965. "A Head of Herakles in the Philadelphia University Museum." American Journal of Archaeology 69.2: 156-160.

This paper is posted at Scholarship, Research, and Creative Work at Bryn Mawr College. https://repository.brynmawr.edu/arch_pubs/178

For more information, please contact repository@brynmawr.edu. 
was not done, as the coins had presumably been cleaned within recent history, and moreover it was desired to use the non-destructive feature of the technique as it was not permissible to damage the coin.

The technique of $\mathrm{x}$-ray fluorescence has proven useful in problems of this kind, where simplicity of manipulation, speed of analysis, and preservation of the intact specimen is essential, and where the specimen is homogeneous enough to admit analysis of only the surface.

Our thanks are due Mr. E. Gans, who lent the coins from his collection and suggested the correlation with Miss Thompson's work, Mr. J. R. Weaver who gave helpful advice on the analysis, and the Shell Development Company, who authorized this work. We are also grateful to Miss Thompson, whose criticism has been most valuable.

SHELL DEVELOPMENT COMPANY

T. C. $Y_{\text {AO }}$

F. H. Stross

EMERYVILLE, CALIFORNIA

\section{A HEAD OF HERAKLES IN THE PHILADELPHIA UNIVERSITY MUSEUM*}

PLATES 43-44

It sometimes happens that what is considered to be a Greek original turns out, upon further study, to be a Roman copy. More seldom does it occur that what is thought to be a Roman copy proves instead to be a true Greek work. This, however, may be the happy case with a small marble head of Herakles in the University Museum in Philadelphia (pls. $43-44$, figs. I-6). ${ }^{1}$

This interesting piece is virtually unpublished. It received a brief mention in S. B. Luce's Catalogue of the Mediterranean Section of the University Museum, ${ }^{2}$ where it was summarily described as Dionysos crowned with ivy leaves, and labeled "a Roman copy of a late Greek original." Since we believe that the head rep-

* We are deeply indebted to the authorities of the University Museum, Philadelphia, for permission to study and publish this piece. The photographs of the, Philadelphia head are by Karl Dimler, of Bryn Mawr College.

${ }^{1}$ No. MS 4031 . According to the Museum file card, the piece was purchased from Dr. Paul Arndt and presented to the $\mathrm{Mu}$ seum by Mrs. L. W. Drexel in 1904. The provenience of the head is unknown.

2 Philadelphia I921, no. I5, pp. I88-189. The complete entry reads: "Small male head of marble, about one half life size. The face is bearded, and the hair is very thick, and crowned with a wreath of ivy leaves. It has been suggested that the head is of Herakles, but the garland suggests the mature bearded Dionysos. This is a Roman copy of a late Greek original. Its provenance is unknown. Accession no. MS 403I. Height, ca. $20 \mathrm{~cm}$."

${ }^{3}$ Here and henceforth all mentions of sides refer to proper right and left. Dimensions:

Total height: $18.5 \mathrm{~cm}$.

Height of face (from top of forehead to chin): $10.5 \mathrm{~cm}$.

Total depth (from tip of nose to back of garland): $13.4 \mathrm{~cm}$.

Width (between temples): $7.2 \mathrm{~cm}$.; (from ear to ear, front): resents instead the hero Herakles garlanded with vine leaves, dating from around 300 B.C., a complete description of the piece seems in order.

Approximately half lifesize, ${ }^{3}$ the head must have once belonged to a full statue. It broke off at the neck along a slanted surface which preserved most of the neck on the right, very little of it on the left. ${ }^{4}$ This diagonal break might have been determined by the original position of the head, somewhat turned to the left (as indicated by the tensed right sternomastoid) and slightly inclined toward that shoulder. This position, though partly obscured by the incorrect attachment of the piece to its present stand, is corroborated by the rendering of the fillet binding the leaves. The ends of the band hang loosely over the shoulders, the right end falling almost vertically along the preserved portion of the neck, beginning to curve gently into the horizontal only at the point of break; but the left end of the fillet stretches diagonally away from the neck, suggesting that it met with some obstacle shortly below the present line of preservation. Slight asymmetries in facial features and other details, to be discussed below, are in keeping with this reconstruction.

The head portrays a mature man, with closely cropped hair and beard, and a full moustache curling down and inward over the corners of the slightly parted mouth. The face has a rather narrow and sloping forehead, indented at the temples and horizontally divided by the protrusion of the eyebrow muscle forming the so-called "Michelangelo bar." In spite of this protrusion and of the resultant deep-set eyes, the expression is neither angry nor pathetic; rather it may suggest a moment of rest and serene contemplation in a man whose active life has left permanent traces in the hollowing of his features and the unconscious knitting of his brow.

Equally sensitive is the treatment of the cheeks. Defined by eyelids, nose, moustache and beard, they are not blank intermediate spaces, nor are they lined by harsh grooves. They swell and sink in a subdued play

$8.7 \mathrm{~cm}$; (rear): $9.3 \mathrm{~cm}$.

Width of neck: $8.25 \mathrm{~cm}$.

Eyes: length from exterior: (right) $2.2 \mathrm{~cm}$; (left) $2.05 \mathrm{~cm}$.

length of eyeball: (right) I.8 cm.; (left) $1.7 \mathrm{~cm}$.

greatest height between lids: (right) $0.7 \mathrm{~cm}$.; (left) 0.65 $\mathrm{cm}$.

distance between inner corners: $1.35 \mathrm{~cm}$.

Length of nose: $2.75 \mathrm{~cm}$.

Width of mouth opening: $2.4 \mathrm{~cm}$.

4 The head is in good condition, the only major damage being in the area of the nose, where a triangular break from left side of bridge to tip has removed the original surface, uncovering the left nostril. The forehead is chipped in three places, the deeper indentation cutting through the right eyebrow. The underside of the beard adhering to throat and chin has two damaged areas on either side of the central parting. Several leaves in the garland have broken edges. The entire surface of the piece, including the break at the neck, is covered with incrustation, obviously mortar, suggesting that the head, in its broken condition, was at some time re-used as building material. Traces of red coloring appear on the hair and beard. 
of light and shadow. Stretched tightly over the zygomatic bones (which are spaced rather far apart), the skin then rises over the soft fleshy area near the moustache, while a deep indentation outlines the nostril. The full lips, parted by a groove and surrounded by swelling locks of beard and moustache, display the same subtle modulation of surface.

In contrast with these modeled areas other features present a more linear treatment. Despite heavy masses of Alesh overhanging their outer corners, the eyes themselves are relatively shallow and finely drawn, the right one slightly different from the left in dimensions and execution. ${ }^{5}$ The upper lids form well-defined ridges, while the lower lids merge gradually into the modeling of the cheeks. The convex eyes bear no markings except the faint arc of the canthus and the minute drill hole of the inner corner. ${ }^{6}$ Equally linear is the rendering of the beard: its comma-shaped locks, subdivided by shallower lines which make them appear fuller, are arranged in regular rows rising to meet the hair. At the tip of the chin the beard parts in a whirllike arrangement; otherwise it lies close to the face leaving the neck uncovered. The rendering of the moustache is more fluid, the minute locks increasing in thickness toward the tips, where they overlie the beard without merging with it.

The artist who executed the Philadelphia head was keenly aware of textures. He conceived his composition as a nucleus of modeled features ${ }^{7}$ surrounded and enhanced by areas of coarser and broken appearance. Within this general scheme the mouth-an island of modeling framed by linear motifs-repeats in a minor key the tone of the whole. The rough texture of the lower half of the face is matched by the uneven surface of the upper half, beard counter-balancing garland. The wreath dominates: though some locks are visible from under the garland, the major motif is carried by the vine leaves, with their linear venations and the punctuation of the drill holes marking the lobations $;^{8}$ the ears, small and swollen, are not sufficiently emphasized to break the pattern of leaves and locks, and, lying close to the skull, fuse with beard and garland.

The back of the head (pl. 44, fig. 6), in contrast with this accurate rendering of the front view, is singularly perfunctory. Though the sculptor had un-

\footnotetext{
5 Beside being longer and larger, the right upper lid is less protruding and overlaps the lower lid at the outer corner.

${ }^{6}$ In proportion to the head, the eyes are perhaps rather small and too close to the nose, which also appears too short in relation to the other features.

${ }^{7}$ Even the eyebrows are rendered only plastically, so that no incision breaks the smooth heaving surface.

${ }^{8}$ Each leaf is composed of a main stem, deeply outlined, and an incised main vein branching out into four minor ridges with secondary ramifications. Drill holes and shallow grooves mark the five lobations of each leaf. There are ten leaves to the garland, tied by a fillet in an inner and outer circle and alternating at the two levels. Carved in fairly high relief, the wreath frames the face in front and continues toward the back above and behind the ears and on either side of the knot over the
}

hampered access to this rear portion (no part of it being free from tooling), he carried out his patterns as mere outlines. The section of hair enclosed by garland and fillet appears as a concentric system of clockwise and counterclockwise swirls around a central depression, the individual locks rendered only by contours. The knot of the fillet is flat and undetailed; the portion of nape and neck framed by the hanging bands is peculiarly flat and smooth. The back of the head is the only part of the work where tool marks were not removed in a final polishing of the surface, and thus is further evidence that the statue was not intended to be seen from the back.

But we can perhaps determine even more precisely the main view of the head: seen from the front (pl. 43 , fig. 4), the face presents asymmetries which indicate a three-quarter torsion of the head to the left, the position suggested by the turn of its neck (cf. pl. 43, fig. I). We have already mentioned the different treatment of the two eyes. Further, the left cheek appears less carefully modeled than the right. The left temple is more deeply indented; the garland lies farther away from it $^{9}$ and casts a shadow against the face. The left ear is less detailed, its orifice more mechanically outlined. The grooves in the fillet on that side retain undisguised traces of the drill. Clearly, then, the head was meant to be seen in three-quarter view from the right.

This assumption is further confirmed by the state of preservation of the two sides of the head. The surface on the left is better preserved than the stained right side. This discoloration might have been caused by weathering; it cannot be attributed to the re-employment of the marble since only one section is discolored, while traces of mortar appear on all sides, thus implying a complete embedding of the head.

\section{IDENTIFICATION AND CHRONOLOGY}

Ivy and grapevine are comparable in the pattern of their leaves; indeed, Dionysos is often represented with ivy, probably because of this plant's resemblance to the grapevine. ${ }^{10}$ But plastically the leaf of the vine is rendered with prominent lobations, while the ivy leaf appears heart-shaped and with a more continuous outline. ${ }^{11}$ We believe that the wreath on the Philadelphia head is of vine leaves.

nape. There are minor variations so that one side of the garland is not identical with the other, and the pattern of alternating leaves is not obvious at first glance.

9 Thus becoming visible even from a three-quarter view; cf. pl. 43 , fig. I.

${ }^{10} R E$ I I :2, cols. 1588-1607, s.v. "Kranz"; see esp. col. I592: "Epheu ist nur ein Surrogat und konnte dieses sein wegen der grossen Ähnlichkeit seiner Beeren mit den Weintrauben."

11 These vegetal ornaments appear in significant contrast in the group of Silenos holding the infant Dionysos in the Vatican (Amelung, Katalog I, Braccio Nuovo, pp. I6-17, pl. 2; Bieber, M., Sculpture of the Hellenistic Age, 2nd ed., New York 1961, fig. 85). The two human figures are crowned with ivy, while larger vine leaves and bunches of grapes entwine around the pillar on which Silenos leans. For an unquestionable instance of 
Both ivy and vine, though typical attributes of Dionysos, are also associated with Herakles. ${ }^{12}$ A close connection-almost a contamination-exists between the hero and his half-brother Dionysos, attested not only by frequent joint representations but also by common attributes. ${ }^{13}$ Moreover, Herakles is entitled to a vine wreath in view of his propensity for frequent libations, ${ }^{14}$ a characteristic of the hero stressed in Euripides' Alkestis, ${ }^{15}$ and often depicted in small bronzes. ${ }^{16}$ A drunken Herakles wreathed with vine leaves (perhaps after a large-scale sculpture) appears also in a Pompeian painting showing the hero at the court of Omphale. ${ }^{17}$ The garland of vine leaves may therefore be considered not merely the whim of the artist or a reminder of Herakles' relationship with the god of wine, but also an attribute almost as characteristic as club and lionskin.

The wreathed Herakles often appears on vases depicting banquet scenes, either alone or with other deities. ${ }^{18}$ A famous work by Lysippos, the Herakles Epitrapezios, may derive its epithet not from its function as small silver ornament over Alexander's table, but from its convivial pose. ${ }^{19}$ This feasting could be interpreted as a celebration after Herakles' efforts to attain immortality, the crown then symbolizing his apotheosis. ${ }^{20}$ Furthermore, Herakles was initiated into the lesser Eleusinian Mysteries, during which ceremony he probably donned the customary garland of vine

ivy leaves cf. also the many maenad reliefs, e.g. Richter, Catalogue of Greek Sculpture in the Metropolitan Museum, Cambridge, Mass., 1954, no. 58, pls. 50-51.

12 See esp. Murr, J., Die Pflanzenwelt in der griechischen Mythologie (Innsbruck I 890) 293, s.v. "Herakles," and more specifically pp. I $4 \mathrm{I}, \mathrm{I} 46$.

$13 \mathrm{~J}$. Bayet, Hercule, étude critique des principaux monuments relatits à l'Hercule Étrusque (Paris 1926) 143; Metzger, H., Les représentations dans la céramique attique du IVe siècle (Paris 1951) 190, 219-220, 228; for the earliest example in sculpture of the association of the two deities, cf. Picard, Ch., Portes sculptées, Études Thasiennes VIII, p. 80 and n. 2; see also Murr, op.cit. (supra n. 12) 146.

14 F. Poulsen (Catalogue, Ny Carlsberg Glyptotek [Copenhagen 195I] I9I), writing about a vine-garlanded head of Herakles, states: "Appearance of vine leaves, which are also to be seen on other replicas, must not confuse the head with Dionysos. Herakles is such a wine bibber that it is natural to find him garlanded as for a symposium."

15 "[in this play] ... the hero's drunken praises of love and wine form the foil to his strenuous labours and heroic enterprise," says E. A. Gardner (Six Greek Sculptors [London 1925] 23I), giving a likely explanation of the popularity of this characterization.

${ }^{16}$ Cf., e.g., Bieber, op.cit. (supra n. II) 140, figs. 577-8o; D. K. Hill, Catalogue of Classical Bronze Sculpture in the Walters Art Gallery (Baltimore 1949) 98, pl. 22, etc.

${ }_{17}$ Pfuhl, E., MuZ (Munich 1923) no. 664, pls. 283-284.

18 One of the most famous is the bilingual amphora by the Andokides Painter in Munich, Cook, R. M., Greek Painted Pottery (London 1960) pl. 38. Cf. also Metzger, loc.cit. (supra n. 13).

19 Several scholars advocate a monumental prototype for Alexander's statuette. See Dörig, J., "Ein lysippisches Heraklesköpfchen in Basel," $A M$ 7I (I956) I84 and n. I7, I88 and leaves. ${ }^{21}$ Finally, ancient sources contain mythological accounts of Herakles' connection with the grapevine, and refer to satyric plays and vase paintings based on these myths. ${ }^{22}$ Herakles would seem entitled to a wreath of grapevine on four counts: his family association with Dionysos; his predilection for wine, frequently portrayed in art and literature; his initiation into the lesser Eleusinian Mysteries; and mythological accounts.

The proof for the identity of the head rests, however, not on the appropriateness of the garland, but on the features themselves. Herakles, as well as Dionysos, appears in art bearded and beardless. The hero is shown clean-shaven from the Severe period down to Roman times to emphasize his youth at the inception of his cycle of labors; the god tends to appear younger especially during the fourth century and the early Hellenistic period. The considerable difference between the two beardless types-Herakles, a vigorous and virile athlete, Dionysos, languorous and slightly effeminateprevails also in their bearded iconography. The god of wine is a majestic and venerable figure, with long flowing hair and luxuriant beard covering his chest; Herakles displays shorter hair, and his beard, though at times longer than that of the Philadelphia head, is never long enough to impede swift action; the closely cropped style stresses the energetic appearance of the hero, rather than his patriarchal aspect. ${ }^{23}$ In our piece, aside from hair and beard, other traits tend to confirm

n. 47; see also D. de Visscher, Heracles Epitrapezios (Brussels 1962).

20 Cf. Metzger, op.cit. (supra n. 13) 222.

21 Since the hero was a foreigner, he could not be admitted to the greater Mysteries, therefore the lesser ones were instituted for his benefit. Cf. Mylonas, G., Eleusis and the Eleusinian Mysteries (Princeton 1961) 240; also 210-211, fig. 85.

22 C. Aelian, De Natura Animalium 6.40: "There is an island in the Black Sea named after Herakles which has been highly honoured. Now all the Mice there pay reverence to the god, and every offering that is made to him they believe to have been made to gratify him and would not touch it. And so the vine grows luxuriantly in his honor and is reverenced as an offering to him alone, while the ministers of the god preserve the clusters for their sacrifices. Accordingly when the grapes reach maturity the Mice quit the island so that they may not, by remaining, even involuntarily touch what is better not touched. Later when the season has run its course they return to their haunts. This is a merit of the Pontic Mice" (trans. A. F. Schofield).

Apollodoros, Bibl. 2.6.3: "Eurytus did not accept the compensation when it was presented to him, but Heracles served Omphale as a slave and in the course of his servitude he seized and bound the Cercopes at Ephesus; and as for Syleus in Aulis, who compelled passing strangers to dig, Heracles killed him with his daughter Xenodice, after burning the vines with the roots" (trans. J. G. Frazer).

See also Tragicorum Graecorum Fragmenta, ed. A. Nauck, 575; and Murr, op.cit. (supra n. I2) I4I.

${ }^{23}$ For a typical representation of the bearded Dionysos see the so-called Sardanapalos type, Rizzo, E. G., Prassitele (Milan 1932) pls. I 44-I 47; cf. also the Hellenistic Ikarios Relief, Bieber, op.cit. (supra n. II) figs. 656-657. The bearded Herakles will be discussed infra. 
our identification: the short thick neck, the swollen ears and the Michelangelo bar, this last typical of Herakles' representations from the fourth century onward, especially within the Lysippean circle.

These iconographical considerations bring us to the problem of chronology. Typologically, the bearded Herakles could belong to any period of Greek and Roman art, since the presence or absence of beard points to a stage within the life of the hero rather than to a phase of artistic production, as in the case of Dionysos. It may seem at first that the presence of the garland and its execution provide a chronological clue. Roman copyists are known often to have added attributes of leaves and fillets to their replicas of Greek originals, ${ }^{24}$ while the practice of accenting lobation patterns by means of drill holes seems typically Roman and is employed for freestanding statuary as well as for architectural decoration. ${ }^{25}$ Garlands, however, existed in Greek originals also. ${ }^{26}$ In addition to instances of bronze leaves attached to marble heads, ${ }^{27}$ and bronze figures wearing bronze wreaths, ${ }^{28}$ there exist marble originals with marble garlands; ${ }^{29}$ Herakles, often garlanded in vase painting, must have been similarly represented in Greek statuary in the round. According to C. C. Vermeule ${ }^{30}$ there were at least two such types, one going back to the fourth century B.c. with possible ancestry in Polykleitan circles, the other dating at least from the third century, and possibly within the school of Praxiteles. ${ }^{31}$ The vine wreath on the Philadelphia head is therefore compatible with our suggested chronology. Nor is the technique of incision and

$24 \mathrm{Cf}$. A. Furtwängler, in Roscher's Lexikon I:2,2167, who gives as a typical example the Genzano herm in the British Museum, no. I73I (Bulle, SchMsh 2II), stemming from the same original as the ungarlanded Lansdowne Herakles, $\mathrm{Br} . \mathrm{Br}$. 691-692. See also Mansel, A.M., et al., Side Agorasi ve Civarindaki Binalar (Ankara 1956) 63 and figs. 94-96, for a replica of the Farnese type with added wreath. For metal garlands in Greek originals reworked in marble by copyists see also G. Hafner, Ein Apollon-Kopf in Frankfurt (Baden-Baden 1962) 13 and bibliography cited in note 5 .

${ }^{25}$ Cf. e.g. Severan architecture, D. E. Strong, Roman Imperial Sculpture (London 196r) fig. II4, decorated pillar in the Lateran; M. Squarciapino, La Scuola di Afrodisia (Rome 1942) pls. L,b; 28,29 and $30, \mathrm{~b}$, pilasters of the Severan Basilica at Lepcis Magna. In statues: head of Herakles, Copenhagen I.N. 1593, Poulsen, Catalogue no. 269, p. I99, EA 42894290 whence our pl. 44, fig. 8 (see also infra, final paragraph); head of youthful Herakles in Rome, EA 152-153; etc.

${ }^{26}$ Sometimes this inference can be drawn from the concordance of copies in some details. For instance, all the replicas of the Sylenos with infant Dionysos (supra n. II) agree in the detail of the, wreaths, which must therefore have been present in the original group.

27 Cf. e.g. a fourth century B.c. head in New York, Richter, Catalogue no. 93 , p. 62 , pl. 75 c,d.

${ }^{28}$ Cf. e.g. Bieber, M. "A Satyr in Pergamene style in Kansas City," AJA 67 (1963) 275-278, pls. 59-6o, dated ca. 200 B.c.; the arrangement of ivy garland and fillet is close to that of the Philadelphia head.

${ }^{29}$ Cf. e.g. the Barberini Satyr in Munich, late third century B.c., Lullies and Hirmer, Greek Sculpture (2nd ed. New York 1960) figs. $248-249$. drill holes a deterrent to a Greek attribution. Perhaps the most cogent parallel (though the leaves are somewhat more elongated in shape) is the frieze on the lid of the Alexander sarcophagus ${ }^{32}$ of the end of the fourth century в.c. Similar accents of shadow in vegetal motifs of a different nature appear in Corinthian capitals at Epidauros and elsewhere in the Peloponnese. ${ }^{33}$ This practice, so popular in Roman and even in Byzantine times, can therefore be traced back to classical Greece.

Our chief criterion for dating the Philadelphia head cannot be the garland, since as many examples can be adduced for a Roman as for a Greek attribution. Equally, none of the following points by itself constitutes definite proof, but their sum total points toward a dating around 300 B.c. I) The workmanship of the piece is excellent. The head entirely lacks the cold and lifeless quality which artisans often imparted to mechanical replicas. The iris and pupil are not incised. The treatment of hair and beard displays no coloristic technique typical of Antonine and Severan times, nor has it the classicizing appearance of Augustan or Hadrianic work. 2) The tooling marks are compatible with a late fourth century date. No traces of the flat chisel appear. The smooth but opaque surface of the marble is comparable only to Greek originals; its warm coloring is atypical of Italian materials. ${ }^{34} 3$ ) The perfunctory carving of the back of the head, though found also in Roman copies, is not unknown in Greek originals. ${ }^{35}$ It cannot be explained by supposing that our head formed part of a figure in high relief

30 "Herakles crowning himself," JHS 77 (1957) 283-299; esp. 298.

${ }^{31} \mathrm{~A}$ garlanded herm in the Conservatori (Galleria 28) is defined by B. Ashmole (JHS 42 [1922] 242-244) a faithful copy of a fourth century B.c. original with strong stylistic affinities to the Hermes of Olympia. Ashmole however maintains that the head represents Dionysos and not Herakles, as generally believed.

32 Lullies \& Hirmer, op.cit. (supra n. 29) pl. Ix, figs. 231-232.

${ }^{33}$ Cf., e.g., G. Roux, L'architecture de l'Argolide aux IVe et IIIe siècles avant J.C. (Paris $196 \mathrm{I})$ pl. 48.

34 The marble resembles Pentelic in its tone, but its grains are perhaps too coarse to be Attic. Unfortunately the provenience of the head is unknown and we have been unable to determine the origin of the medium. If the stone were Asiatic, the excellent workmanship could be explained, since often Asia Minor copyists carved outstanding works. The treatment of the leaves finds parallels in Roman sculpture attributed to the School of Aphrodisia (see supra n. 25, M. Squarciapino). Cf. also J. B. Ward Perkins, "Severan Art and Architecture at Lepcis Magna," JRS 38 (I948) 72, but our piece lacks the highly polished surface characteristic in works of the Carian circle.

${ }^{35}$ Aside from the controversial Hermes of Olympia, cf. L. D. Caskey, Boston Catalogue (Cambridge, Mass. 1925) no. 4I, pp. 92-93, for a fourth century statue of a boy with asymmetrical facial features and hair only roughly blocked out on the top and back of the head. A copyist, using the pointing process, would have probably finished the hair completely or left it entirely undone. The rendering of our head suggests the classical approach of working a piece from all sides at all stages. 
rather than in the round. Several Roman sarcophagi represented Herakles' labors in a metope-like arrangement, each deed contained within a niche, ${ }^{36}$ but the hero, though almost emerging from his frame, was still effectively anchored to the background, a condition which would have prevented the complete tooling of the rear surface noticeable in our piece.

If the Philadelphia head is indeed an original, no exact parallel to it should exist, and we have been unable to find any. The piece can, however, be placed in a context of sculptural works typologically and stylistically related to it. The modeling of forehead and cheeks-subtle rather than emphatic-the slightly idealized facial features, the rendering of the eyes, the orderly yet not monotonous pattern of the beard, seem to point to the end of the fourth century B.c. or the beginning of the Hellenistic period. In later art Herakles tended to appear pathetic and weary, a formidable man who had undergone formidable hardship. Our head conveys maturity rather than old age, vigor rather than fatigue. At first sight it resembles Lysippean works, especially of the Farnese type; ${ }^{37}$ on actual comparison, the Philadelphia Herakles has a shorter and less luxuriant beard, a less troubled expression. It is closer in type to a head in Boston ${ }^{38}$ whose features are, however, less idealized and more "pathetic." A more complete replica of the Boston type exists in Copenhagen; ${ }^{39}$ the end of the club below the left armpit shows that the hero was leaning on his weapon, a stance foreshadowing the later Farnese type. The turn and inclination of the head in the $\mathrm{Ny}$ Carlsberg statue resemble the Philadelphia piece; since the motif of the resting hero proved popular in antiquity ${ }^{40}$ the lost body of our work might have been in a similar pose. ${ }^{41}$ This assumption is made also about a Hellenistic head of Herakles from Thasos (pl. 44, fig. 7).42 The expression is here definitely frowning, the eye treatment more realistic, the modeling of the cheeks more pronounced. Yet the Thasian head, with its compact beard and hair, exemplifies the same artistic approach as in the Philadelphia piece and illustrates the development of the bearded Herakles type along more plastic and veristic lines. An over-lifesize head from

${ }^{36}$ Cf. E. Loeffler, "Lysippos' Labors of Hercules," Marsyas 6 (1950-53) 8-24, pls. Iv, viI:I; for a recent find, see ILN April 6 , $1963,500-501$.

${ }^{37} \mathrm{Br} . B r .284-285$; Bieber, op.cit. (supra n. II) figs. 79, 84 .

$38 \mathrm{Br} . \mathrm{Br} .735$; Caskey, Catalogue no. 74, pp. I 49-1 50, "probably to be dated in the second half of the 4th century B.c." by an unidentified sculptor "strongly under the influence of Skopas." This head and several others similar to it are considered Lysippean in an article by K. Schauenburg in Antike Plastik II, 75ff, pls. 46-7I, which unfortunately appeared too late to be considered in this note.

${ }^{39} \mathrm{Br} . \mathrm{Br}$. 734. Poulsen, Catalogue no. 250, I. N. I720, pp. I 88-I 89, copy of a work by "an Attic artist in the beginning of the $4^{\text {th }}$ century B.c."

${ }^{40}$ Several other compositions were created along the same lines. G. M. A. Richter, Ancient Italy (Ann Arbor 1955) 44-55, advocates that "modifications of a well-known type are probably due not to the Roman copyist but to derivation from a different
Pergamon ${ }^{43}$ echoing the Lysippean Epitrapezios moves a step further in that direction. All the traits of our piece appear, emphasized and dramatized, in the Hellenistic work, accenting by contrast the classical restraint of the Philadelphia Herakles. Indeed, Hellenistic sculpture does not provide close parallels, and our head can be more successfully compared with fourth century works-even if not representations of Herakles -for the rendering of individual traits. A head from the Mausoleion at Halikarnassos, ${ }^{44}$ for instance, has similar beard and eyes; the eyes of an elderly man on an Attic funerary relief of around 320 B.c. bear an even closer resemblance; ${ }^{45}$ the parted, fleshy lips, the upper one dipping in the center, recall the mouth of the Hermes of Olympia.

All these comparable pieces, however, lack the most conspicuous feature of the Philadelphia head: its wreath. For this reason our best parallel is perhaps a "cheap Roman decorative work" of the second century A.D. after a fourth century B.c. original (pl. 44 , fig. 8). ${ }^{46}$ Nose, upper lip and neck are restored, and the hand of the copyist is visible in the treatment of hair and beard. Several dissimilarities exist, such as the prominent ears, the forehead locks emerging from under the garland, the deeper shadow around the eyes, the narrower face. The head also lacks the subtle contrast of surfaces so skillfully handled in our piece. Yet, typologically, this Roman Herakles is closely related to the Philadelphia one: as a foil it provides perhaps the best commentary, the most convincing proof of the high quality of our Greek original.

\section{Elizabeth T. Wakeley \\ BRUnilde Sismondo RIDGWay}

BRYN MAWR COLLEGE

\section{A NOTE OF CORRECTION}

In a recent article, "The Appearance of Neolithic Black Burnished Ware in Mainland Greece," ${ }^{1}$ Holmberg refers twice to the bothros excavated in Trench 3 at Elateia. ${ }^{2}$ His first mention ${ }^{3}$ stresses the fact that the black ware from the bothros was "found together with Neolithic Urfirnis and black-on-red wares. It is

Greek original" (p. 47).

41 A seated pose cannot however be excluded.

42 Briefly published by H. Sitte, ÖJh 40 (1908) 159-160, it appeared later on the English antiquarian market. We owe this reference and the excellent photograph of the piece to the generosity of Prof. C. C. Vermeule, III.

${ }^{43}$ Berlin 1226, $A M 32$ (1907) 379-380, pl. 20; Bieber, op.cit. (supra n. II) fig. 476 (here the museum no. is given as I675); F. de Visscher, op.cit. (supra n. 19) pl. 8, fig. I2.

44 B.M. 1054, Buschor, E., Maussollos und Alexander (Munich 1950) figs. 9-10; Bieber, fig. 73.

45 Athens, N. M. 2574, Lullies \& Hirmer, op.cit. (supra n. 29) pl. 241.

46 Poulsen, loc.cit. (supra n. 25).

\footnotetext{
${ }^{1}$ AJA 68 (1964) 343-348.

2 Hesperia 31 (1962) 1 80-196.

3 AJA 68 (1964) 344.
} 


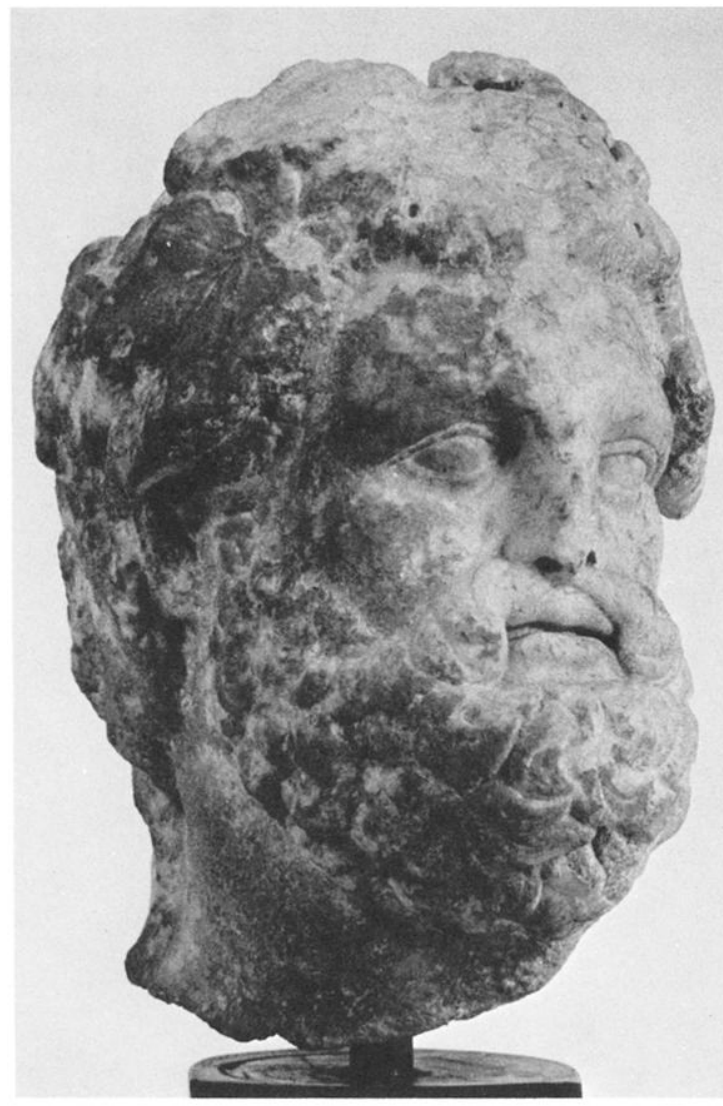

FIG. I

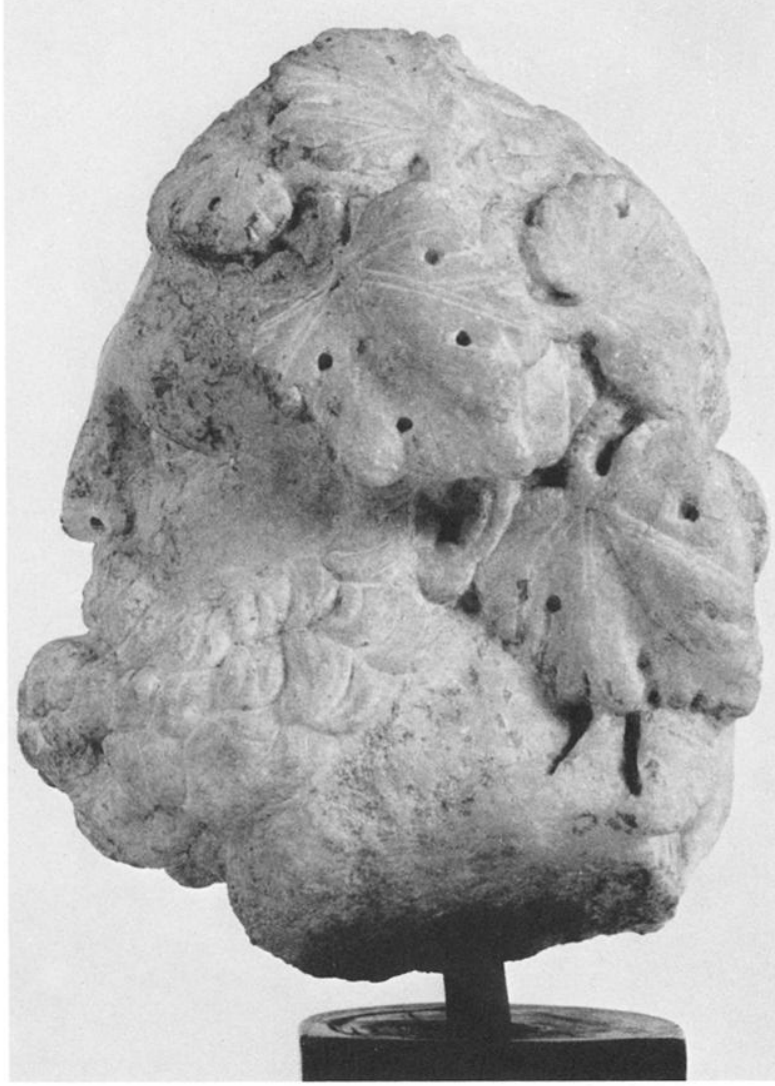

FIG. 3

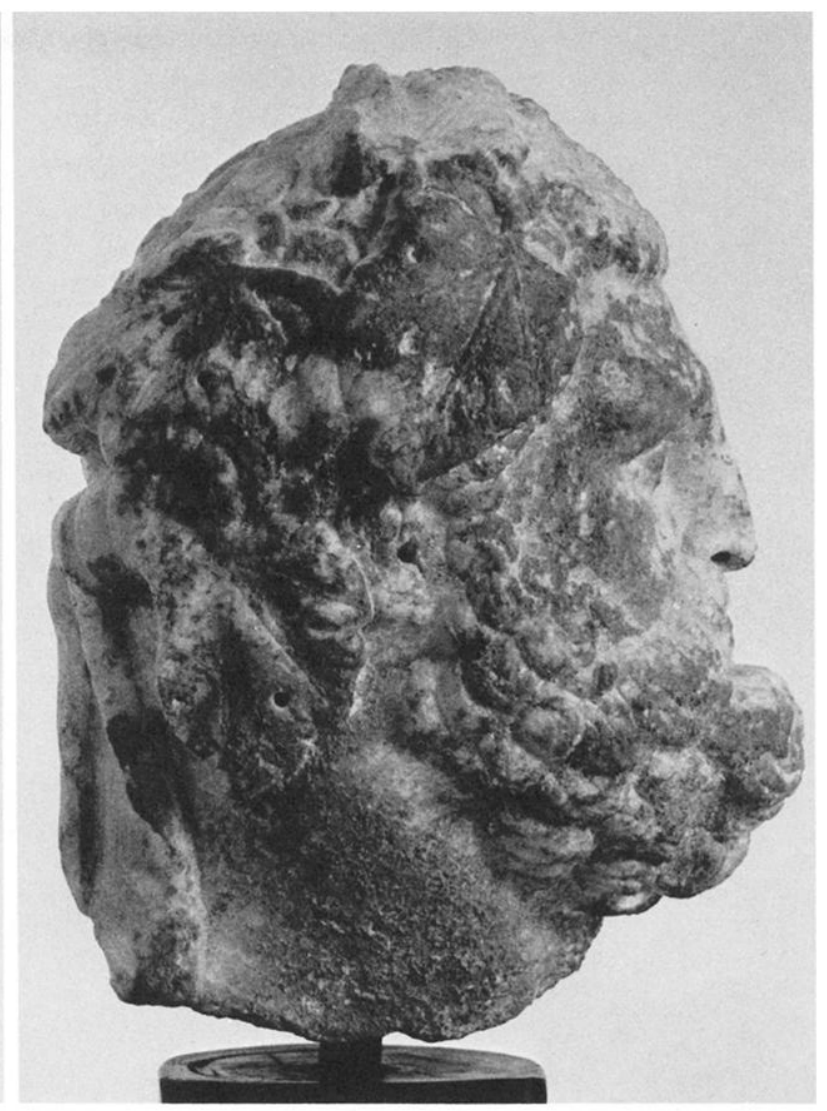

FIG. 2

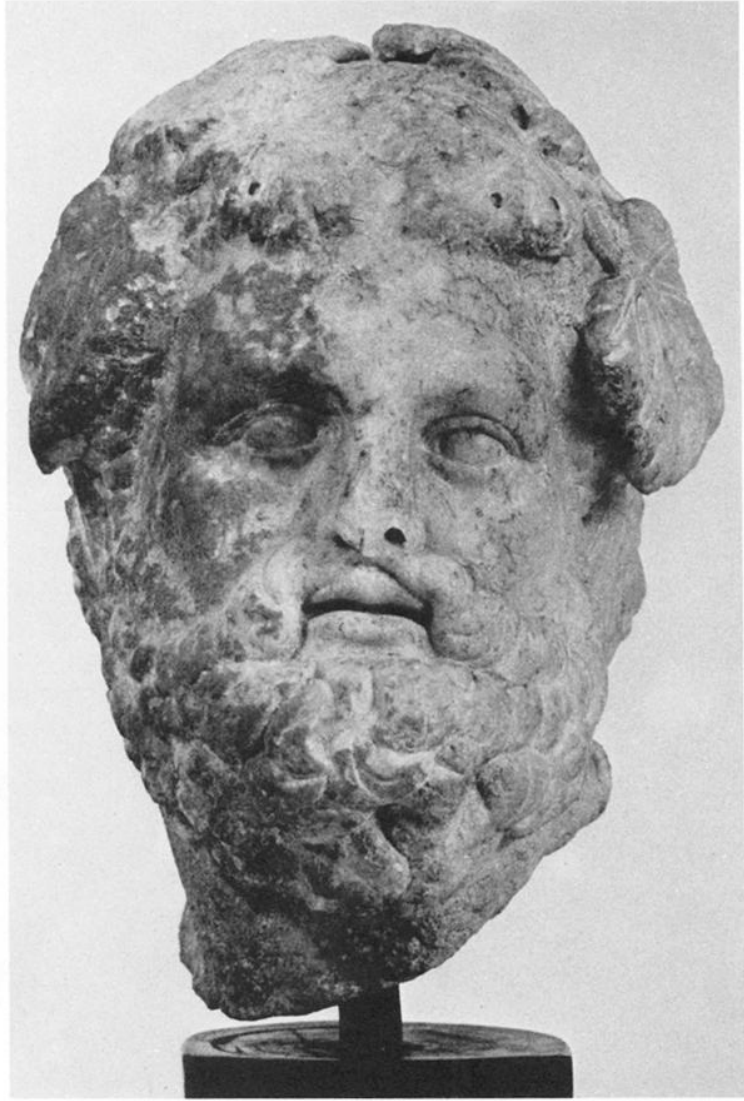

FIg. 4

Figs. I-6. Courtesy University Museum, Philadelphia

This content downloaded from 165.106.132.86 on Fri, 04 Oct 2019 15:09:45 UTC All use subject to https://about.jstor.org/terms 


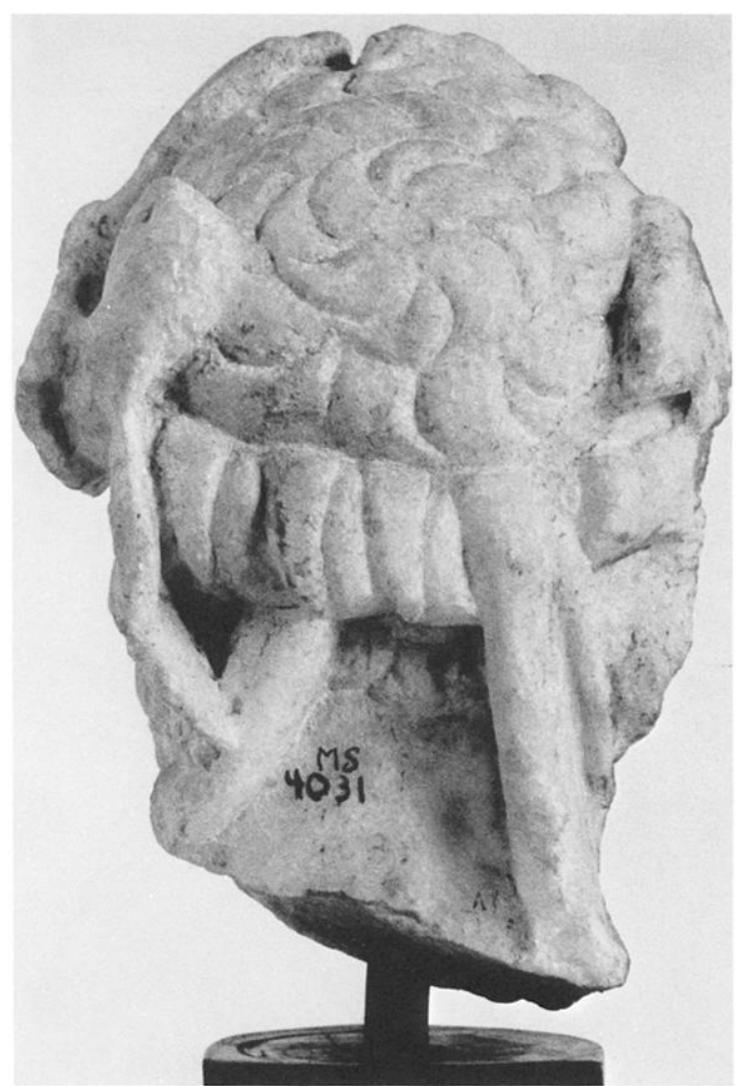

Fig. 5

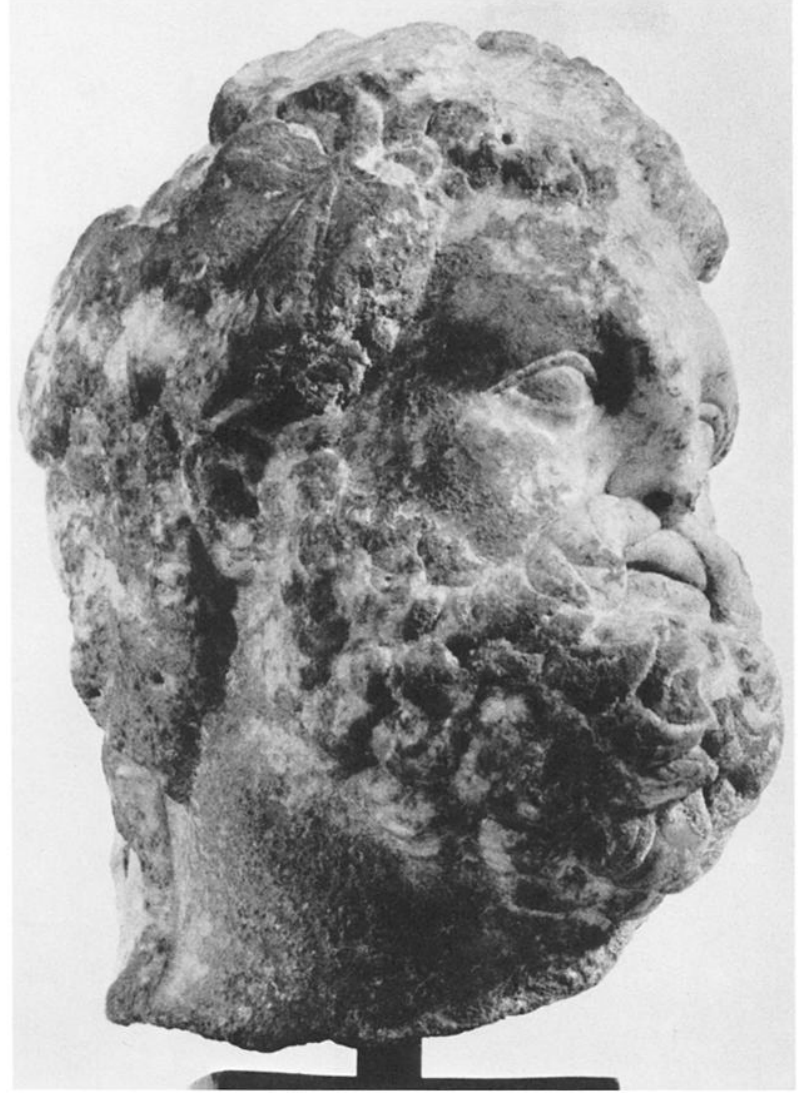

FIg. 6

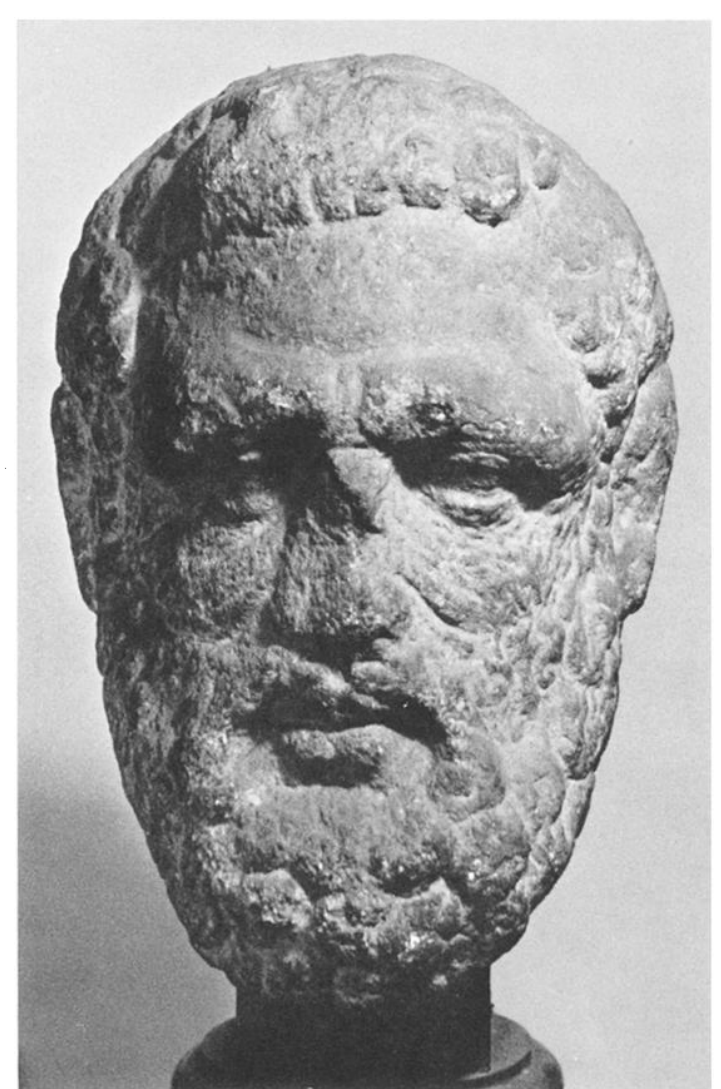

Fig. 7. Hellenistic head of Herakles from Thasos (courtesy C. C. Vermeule, III)

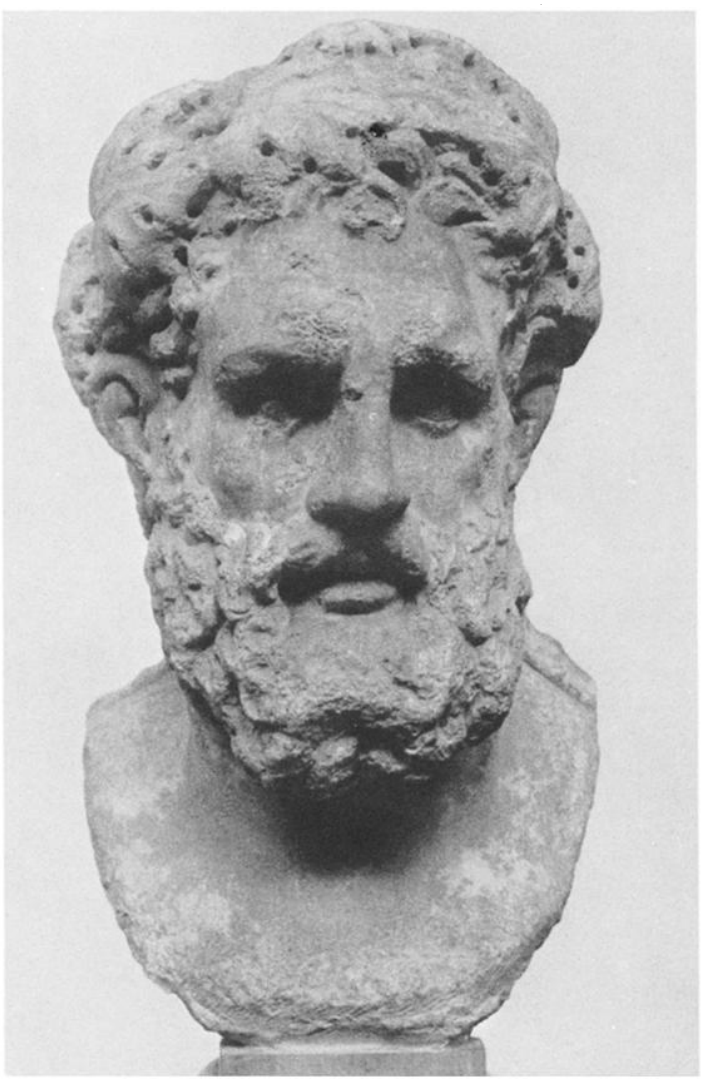

Fig. 8. Head of Herakles, Copenhagen I.N. I593, from $E A \quad 4289-90$ 